\title{
When is entrepreneurial orientation beneficial for new product performance? The roles of ambidexterity and market turbulence
}

Shuangfa Huang, Portsmouth Business School, University of Portsmouth, Portsmouth PO1 3DE, United Kingdom, shuangfa.huang1@port.ac.uk

David Pickernell, Portsmouth Business School, University of Portsmouth, Portsmouth PO1 3DE, United Kingdom, david.pickernell@port.ac.uk

Martina Battisti, Grenoble Ecole de Management, 12 rue Pierre Sémard 38000 Grenoble, France, martina.battisti@grenoble-em.com

Danny Soetanto, Lancaster University Management School, Lancaster University, Lancaster LA1 4YX, United Kingdom, d.soetanto@lancaster.ac.uk

Qihai Huang, Keele Management School, Keele University, Staffordshire ST5 5BG, United Kingdom, q.huang@keele.ac.uk

Address correspondence to: Shuangfa Huang, Portsmouth Business School, University of Portsmouth, Portsmouth PO1 3DE, United Kingdom, shuangfa.huang1@port.ac.uk. Tel: 44 02392844783. 


\title{
When is entrepreneurial orientation beneficial for new product performance? The roles of ambidexterity and market turbulence
}

\begin{abstract}
Purpose Entrepreneurial orientation (EO) is an exploratory orientation because its dimensions such as innovativeness, proactiveness, and risk-taking are the essence of exploration that entails uncertain returns. While literature suggests firms might need to counterbalance and complement EO with another orientation for organisational success, research on this area remains limited. Drawing on organisational learning theory, this study explores whether and how the EO dimensions and organisational ambidexterity complement each other to enhance new product performance. More specifically, we explore the configurations of innovativeness, proactiveness, risk-taking and ambidexterity for superior new product performance under different levels of market turbulence.
\end{abstract}

Design/methodology/approach Based on a configurational perspective, we applied fuzzy set qualitative comparative analysis (fsQCA) on a sample of 88 small and medium-sized firms from the UK. Using fsQCA allows us to uncover the potential complementary role between the EO dimensions and ambidexterity for superior new product performance.

Findings Our findings reveal three configurations that are sufficient to produce superior new product performance. The results suggest that the EO dimensions and ambidexterity can complement each other to enhance new product performance. Further, under the turbulent market environment, the EO dimensions are also sufficient to produce superior new product performance.

Originality/value By adopting a configurational perspective using fsQCA, our study provides a more holistic understanding of how the EO dimensions work together to influence new product performance. It also contributes to the literature by uncovering the complementary role of the EO dimensions and ambidexterity in shaping new product performance.

\section{Keywords:}

Entrepreneurial Orientation; Ambidexterity; New Product Performance; SMEs; Fuzzy Set Qualitative Comparative Analysis. 


\section{Introduction}

In a fast-changing business environment where competition is high and product life-cycles are short, organisations often need to renew themselves through developing and launching new products $(\mathrm{Wu}$, 2012; Wang et al., 2015). Literature suggests one of the determinants of new product performance is entrepreneurial orientation (Hughes and Morgan, 2007), which refers to "the decision-making practices, managerial philosophies, and strategic behaviors that are entrepreneurial in nature" (Anderson et al., 2015, p. 1579). Entrepreneurial orientation (EO) entails three core dimensions: innovativeness, proactiveness, and risk-taking. It captures the propensity of firms to support innovation, being proactive in anticipating consumer demands, and/or engage in risky endeavours (Lumpkin and Dess, 1996). Research has found that the three EO dimensions are associated with new product performance such that innovativeness and proactiveness positively, and risk-taking negatively affect new product performance (Hughes and Morgan, 2007).

Previous research, however, provides only a partial picture about how EO influences new product performance because the dimensions of EO are often examined in isolation (Hughes and Morgan, 2007). As a result, we know little about how configurations of innovativeness, proactiveness, and risk-taking might impact new product performance. It is important to consider the EO dimensions based on a configurational perspective because EO dimensions might work in combinations to influence organisations. Indeed, recent evidence has shown that EO dimensions have "bilaterally shared effects" on organisational outcomes (Lomberg et al., 2016). Additionally, some researchers have highlighted that the EO dimensions such as innovativeness, proactiveness, and risk-taking are exploratory in nature (Wiklund and Shepherd, 2011; Patel et al., 2015). Indeed, exploration concerns activities such as "search, variation, risk taking, experimentation, play, flexibility, discovery, innovation" (March, 1991, p. 71). Hence, it can be argued that EO is an exploratory orientation that entails uncertain returns (March, 1991; Covin and Wales, 2019). While literature has highlighted that firms may need to counterbalance and complement EO with another orientation for long-term success (Covin and Wales, 2019), research on this area remain limited. 
Drawing on organisational learning theory, we posit that organisational ambidexterity might complement the EO dimensions to enhance new product performance. We integrate the literature of EO and organisational learning theory based on following considerations. While EO allows firms to capitalise on potential new opportunities through supporting new ideas, being proactive in anticipating and acting on future demands, and taking risks, a focus on exploring new opportunities alone is not a guarantee for success (Wiklund and Shepherd, 2011; Covin and Wales, 2019). This is because the presence of EO alone does not capture the efficient and effective exploitation of existing opportunities (Covin and Wales, 2019). Indeed, organisational learning theory suggests that the success of organisations depends on organisational ambidexterity, which refers to the capability of firms to simultaneously engage in both exploration and exploitation (March, 1991; Raisch and Birkinshaw, 2008; O’Reilly and Tushman, 2008). For example, studies have found that ambidexterity positively impact new product performance ( $\mathrm{Li}$ and Huang, 2012; Wei et al., 2014). We argue that the EO dimensions, when complemented by ambidexterity, will lead to superior new product performance because the capability to balance exploration and exploitation (i.e., ambidexterity) can safeguard firms from over exploration, which may result from the EO dimensions, at the expenses of exploitation (Gibson and Birkinshaw, 2004). In other words, ambidextrous firms are more likely to capitalise on new product opportunities (Hughes and Morgan, 2007), while at the same time benefiting from the efficiency and stability stimulated by exploiting existing opportunities (Andriopoulos and Lewis, 2009; Simsek, 2009).

Accordingly, the present study aims to answer one research question: whether and how the EO dimensions and ambidexterity complement each other to enhance new product performance? To answer the research question, we adopted a configurational perspective to explore the configurations of innovativeness, proactiveness, risk-taking and ambidexterity for superior new product performance under different levels of market turbulence. Market turbulence represents the extent of changes in consumer demand (Jaworski and Kohli, 1993). It determines the extent to which firms may need to engage in entrepreneurial activities to remain competitive. Under a turbulent market environment, for example, firms might have greater needs to innovate, take risks, and/or being proactive in developing 
new products as their existing products can be short-lived (Rosenbusch et al., 2013). Likewise, firms operate in turbulent environment might have greater needs to refine and renew their knowledge bases and competences due to changing consumer demands (He and Wong, 2004; Gibson and Birkinshaw, 2004). We thus expect the configurations leading to superior new product performance depend on the extent of market turbulence in the environment.

Data from a sample of 88 UK small and medium-sized enterprises (SMEs), firms with more than ten but less than 250 employees (European Commission, 2015), is analysed using fuzzy set qualitative comparative analysis (fsQCA). SMEs are our focus because, due to resource scarcity (Rosenbusch et al., 2011), they have greater needs to configure entrepreneurial activities for successful new product development. Furthermore, evidence suggests SMEs tend to benefit more from the capability to balance exploration and exploitation activities (Cao et al., 2009). We adopted fsQCA because it can help to uncover the potential causal conjunction such that the EO dimensions act in combinations with ambidexterity to influence new product performance. Furthermore, fsQCA can help to identify potentially multiple configurations of the EO dimensions and ambidexterity that are equally effective in producing superior new product performance (Ragin, 2008; Schneider and Wagemann, 2012). This method is increasingly being used in the entrepreneurship literature (Dimov, 2017; Faruk Şahin et al., 2019; Douglas et al., 2020).

The present study expands the literature in several ways. First, it uncovers that innovativeness, proactiveness, and risk-taking tend to influence new product performance in configurations. This indicates that examining the EO dimensions independently (Hughes and Morgan, 2007) or in pairs (Lomberg et al., 2016) provides only a partial picture about their effects on organisations. Our findings based on a configurational perspective provide a more nuanced insights about how the EO dimensions work together to influence new product performance. Furthermore, it contributes to the EO literature and organisational learning theory by uncovering the complementary role of the EO dimensions and ambidexterity in shaping new product performance. As such, our study answers recent calls to examine the factors that counterbalance and complement EO to enhance organisational outcomes (Covin and Wales, 2019). Moreover, it extends the literature on new product performance by adopting a novel 
methodological approach in terms of fsQCA (Ragin, 2008; Schneider and Wagemann, 2012). More specifically, it shows that there are multiple ways for firms to achieve superior new product performance, and firms need to align their activities with the levels of market turbulence in the environment. Finally, our findings offers insights for practitioners on how to leverage the EO dimensions and ambidexterity holistically for superior new product performance.

\section{Theoretical Framework}

\subsection{Entrepreneurial orientation and new product performance}

Research on entrepreneurial orientation (EO) has attracted substantial attention in the past three decades (Miller, 2011; Covin and Wales, 2019). According to Miller (1983, 2011), EO entails three core dimensions: innovativeness, proactiveness, and risk-taking. Innovativeness represents firms' propensity to pursue new ideas and depart from existing practices that may lead to new products or services (Lumpkin and Dess, 1996). Proactiveness reflects firms' efforts to anticipate future consumer demands and launch new products ahead of competitors (Keh et al., 2007). Risk-taking refers to firms' willingness to engage in projects with uncertain outcomes (Wiklund and Shepherd, 2003). We conceptualise EO as a "profile construct" such that combinations of the individual dimensions represent the overall EO profile (Polites et al., 2012). This view is adopted because the individual EO dimensions are likely to vary independently of each other and have distinct impacts on organisations (Andersén, 2010; George, 2011; Miller, 2011; Kreiser et al., 2013).

While researchers have proposed new dimensions of EO (Lumpkin and Dess, 1996), the original three dimensions conceived by Miler (1983) still play a dominant role in the EO literature (Rauch et al., 2009). In particular, Lumpkin and Dess (1996) propose autonomy and competitive aggressiveness as two additional dimensions of EO. Autonomy concerns individuals' independent actions to pursue new ideas and opportunities, whereas competitive aggressiveness reflects firms' tendency to directly challenge their competitors with the aim to outperform them (Lumpkin and Dess, 1996). Consistent with the majority of EO studies (Rauch et al., 2009; Wales, 2016), we focus on the original three core dimensions of EO. Autonomy is not included in our study because the independent actions of 
individuals might not translate into firm-level activities (Edmond and Wiklund, 2010). Competitive aggressiveness is not included because "trying to outrun or outperform one's competitors is indeed a sign of proactiveness" (Basso et al., 2009, p. 318), implying a potential overlap between the dimensions of competitive aggressiveness with proactiveness.

Innovativeness, proactiveness, and risk-taking can influence new product performance in several ways. Innovation allows firms to stand out from the competition and establish a differentiation advantage through their innovative new products (Porter, 1980; Kleinschmidt and Cooper, 1991; Linton and Kask, 2017). The willingness to take risks by committing time and resources for new product development is also critical because without such willingness firms may restrain themselves from pursuing new product opportunities (Hultink et al., 1997). Indeed, firms that are risk tolerant often direct more attention and efforts in pursuing new opportunities (Pérez-Luño et al., 2011; Wiklund and Shepherd, 2003). However, risk-taking entails a chance of failure in new product development (Alvarez, 2007). Furthermore, being proactive in anticipating consumer demands allows firms to establish first-mover advantage (Lumpkin and Dess, 1996) and shape the market environment (Smith and Cao, 2007). Evidence suggests innovativeness and proactiveness positively and risk-taking negatively impact new product performance (Hughes and Morgan, 2007).

Yet how configurations of the EO dimensions influence new product performance remain underexplored. It is important to consider the EO dimensions in configurations for several reasons. First, innovation entails different levels of risk-taking. Developing new products for new markets, for example, are riskier than developing products for existing markets. Likewise, innovation may takes place with different levels of proactiveness. High proactiveness provides firms with the opportunity to reap potential first-mover advantage (Lumpkin and Dess, 1996), whereas being a follower allow firms to learn from competitors (Golder and Tellis, 1993; Srinivasan et al., 2007). Additionally, proactiveness may shape the outcomes of risk-taking. While being proactive allows firms to shape the market environment through new offerings (Smith and Cao, 2007), proactive firms may have less opportunity to benefit from vicarious learning to mitigate uncertainties associated with risk-taking (Srinivasan et 
al., 2007). The above arguments suggest that new product performance is a function of combinations of innovativeness, proactiveness and risk-taking. Therefore,

Proposition la: Innovativeness, proactiveness, and risk-taking can contribute to new product performance, but an individual dimension alone is not sufficient to produce high levels of new product performance.

We also argue that combinations of the EO dimensions are not sufficient to produce superior new product performance. Innovation, for example, is associated with a chance of failure because innovation requires firms to deviate from established practices that may or may not lead to positive outcomes (Rosenbusch et al., 2011). Likewise, while risk-taking may produce high returns, it may result in costly failure due to the uncertainties associated with such efforts (Morgan and Strong, 2003; Alvarez, 2007). Furthermore, acting in anticipation of future demands is not a guarantee for success especially in an environment where consumer demands are changing fast. Indeed, evidence has shown that late entrants can outperform pioneers in both high- and low-technology industries (Schnaars, 2002). Finally, innovativeness, proactiveness, and risk-taking are the essence of exploration that entails uncertain returns (Covin and Wales, 2019; March, 1991; Wiklund and Shepherd, 2011). Thus:

Proposition 1b: Combinations of innovativeness, proactiveness, and risk-taking can contribute to new product performance, but they are not sufficient to produce high levels of new product performance.

\subsection{Ambidexterity and new product performance}

According to organisational learning theory, organisational ambidexterity refers to the capability of firms to simultaneously engage in the learning through exploration and exploitation (March, 1991). In particular, exploration concerns learning activities that are beyond firms' existing product and market expertise (Katila and Ahuja, 2002). It allows firms to expand product-market knowledge base through experimenting with new alternatives. On the contrast, exploitation concerns learning activities that are in the neighbourhood of firms' knowledge base (March, 1991; Baum et al., 2000; Atuahene-Gima and Murray, 2007). It allows firms to enhance efficiency through building upon existing routines and experiences (Simsek, 2009). Previous research has highlighted that organisational success requires 
firms to maintain a balance between exploration and exploitation because over exploration can often lead to many underdeveloped ideas and competences and over exploitation can result in "success trap" (March, 1991; Lavie et al., 2010; Junni et al., 2013).

Ambidexterity represents a dynamic capability that allows firms to create value and maintain competitive advantage through continuously reconfiguring exploration and exploitation (O'Reilly and Tushman, 2008; Teece, 2007). For example, ambidextrous firms can balance and reconfigure their efforts in exploration and exploitation to align with the changing environment (O'Reilly and Tushman, 2008; Simsek, 2009). Ambidexterity can contribute to new product performance in several ways. Exploration allows firms to develop new capabilities and competences through venturing into areas that are beyond firms' current knowledge base (Ferreira et al., 2018; O'Reilly and Tushman, 2008; Tushman and O'Reilly, 1996). As such, the exploration process exposes firms to diverse product and market knowledge domains that may contribute to new product development. Exploitation allows firms to improve their existing capabilities through refining their current knowledge base (March, 1991; Baum et al., 2000; Gupta et al., 2006). Firms can gain greater understanding of the practicality of their current knowledge and expertise through repeated usage (Cao et al., 2009). Hence, the exploitation process can help to avoid mistakes and improve efficiency in new product development (Atuahene-Gima and Murray, 2007).

Ambidexterity can also contribute to new product performance based on the perspective of absorptive capability. According to Zahra and George (2002), firms' capability to identify, assimilate, and use of new knowledge depends on their existing knowledge base. In line with this reasoning, the learning achieved through exploitation can serve as the base of absorptive capability that enhance firms' effectiveness to explore new product and market knowledge. The new knowledge developed will likely contribute to new product development. Likewise, the learning achieved through exploration can expand firms' knowledge base that, in turn, supports the assimilation of new product and market knowledge through further exploitation. Accordingly, exploration and exploitation will likely form a dynamic learning cycle such that they reinforce and complement each other to expand firms' knowledge base (Katila and Ahuja, 2002; Wei et al., 2014). Firms can then leverage their knowledge bases through 
new combinations of product and market knowledge that will likely contribute to new product development.

While ambidexterity will likely contribute to new product development, we suspect ambidexterity alone might not always lead to superior new product performance. Previous research has conceptualised ambidexterity based on the absolute differences between exploration and exploitation (Cao et al., 2009; He and Wong, 2004), indicating a balanced view of ambidexterity. In line with this view, firms are ambidextrous when exploration and exploitation are at similar levels (e.g., balanced), whereas the opposite is the case when exploration and exploitation are imbalanced where one is greater than the other. This implies that ambidexterity might occur when both exploration and exploitation are at high or at low levels. On the one hand, firms are ambidextrous when they devote high efforts on both exploration and exploitation. . On the other hand, firms are also ambidextrous when they devote low emphasis on both types of activities (Gupta et al., 2006). Because some firms might achieve ambidexterity through only low levels of both exploration and exploitation, such firms are unlikely to benefit from the learning and thus the new product and market knowledge that might be gained through exploration and exploitation. As such, they might not be able to achieve superior new product performance. Accordingly, we argue that:

Proposition 2: Ambidexterity can contribute to new product performance, but ambidexterity alone is not sufficient to produce high levels of new product performance.

\subsection{Linking entrepreneurial orientation, ambidexterity, and new product performance}

As argued above, the EO dimensions might not be sufficient to produce superior new product performance as they are exploratory in nature that often entail uncertain returns (March, 1991; Wiklund and Shepherd, 2011; Covin and Wales, 2019). Because ambidexterity deals with firms' capability to balance and reconfigure their efforts in exploration and exploitation (O'Reilly and Tushman, 2008; Simsek, 2009), we suspect ambidexterity might counterbalance the EO dimensions to enhance new product performance. In particular, we posit that the EO dimensions and ambidexterity are likely to complement each other to produce high levels of new product performance. 
We first argue that the EO dimensions when complemented by ambidexterity will likely lead to superior new product performance. EO orients firms to pursue new opportunities through innovation, being proactive in anticipating consumer demands, and taking risks (Lumpkin and Dess, 1996). Hence, EO will promote changes within organisations because firms are required to deviate from existing practices to capitalise on new opportunities (Patel et al., 2015; Wiklund and Shepherd, 2011). However, as Covin and Wales noted (2019, pp. 10-11), "the efficient and effective exploitation of current opportunities is not captured in or particularly relevant to the exhibition of EO”. Firms that exhibit EO without ambidexterity, for example, are likely to over emphasise exploration at the expense of exploitation as the two activities are competing for organisational resources (March, 1991; Gupta et al., 2006). Since ambidexterity allows firms to balance exploration and exploitation (Cao et al., 2009; He and Wong, 2004), ambidextrous firms can thus benefit from the stability and control stimulated by exploitation to counterbalance the change and unpredictability stimulated by the EO dimensions, which are exploratory in nature.

Similarly, there are reasons to expect that ambidexterity contributes to new product performance when it is in conjunction with the EO dimensions. Firms that exhibit ambidexterity without the EO dimensions may miss new opportunities because they are less likely to innovative, take risks, and being proactive in anticipating consumer demands (Lumpkin and Dess, 1996). The absence of EO dimensions indicates that firms only engage in low levels of exploration because EO is an exploratory orientation. Given that ambidexterity concerns firms' ability to maintain a balance in exploration and exploitation, ambidextrous firms with only low levels of exploration (e.g., lack of EO dimensions) are likely to also exhibit low levels of exploitation. Hence, such firms are unlikely to benefit from new product and market knowledge that can be gained through exploration and exploitation. By contrast, when ambidexterity is combined with the EO dimensions, firms can benefit from the opportunity-seeking tendency fostered by EO dimensions, while at the same time benefit from the efficiency and predictability associated with exploitation (Andriopoulos and Lewis, 2009; March, 1991; Simsek, 2009). Taken together, the above arguments suggests the EO dimensions in combination with ambidexterity will likely enhance new product performance. Accordingly: 
Proposition 3: EO dimensions and ambidexterity complement each other to enhance new product performance.

\subsection{The Role of market turbulence}

Research following the contingency perspective suggests the effects of EO and ambidexterity on organisations are contingent on the environment in which firms operate (Raisch and Birkinshaw, 2008; Cao et al., 2009; Uotila et al., 2009; Rauch et al., 2009). We expect the configurations of the EO dimensions and ambidexterity for superior new product performance will differ under different environmental condition in terms of market turbulence. According to Jaworski and Kohli (1993), market turbulence concerns the extent of changes in the preferences of customers. In a turbulent market environment, customer preferences will change rapidly (Miller and Friesen, 1983), implying firms' existing products will become obsolete quickly. Consequently, firms operate under a turbulent market environment have greater pressure to innovate, take risks, and/or being proactive in anticipating consumer demands than firms that operate under a stable market environment.

Likewise, the importance of ambidexterity also depends on the levels of market turbulence in which firms face. In a stable market environment, customer requirements are likely to remain relatively stable (Buganza et al., 2009). This implies that firms have lower pressure to refine and expand their product and market knowledge base to address changing consumer demands (Katila and Ahuja, 2002; Wei et al., 2014). By contrast, in a turbulent market environment, the product life cycles as well as firms' existing competencies will be short-lived (Wu, 2012; Wang et al., 2015). Ambidexterity may be more important under such an environment. The reasons is that the capability to balance and reconfigure exploration and exploitation allows firms to benefit from refining existing capabilities and knowledge base for efficiency, while at the same time expanding and developing new competences and product and market knowledge (Ferreira et al., 2018; Gupta et al., 2006; He and Wong, 2004; Simsek, 2009). That is, ambidexterity enables firms to better response to the competitive challenges caused by market turbulence. Therefore, 
Proposition 4: Configurations of EO dimensions and ambidexterity for high levels of new product performance will vary under different extents of market turbulence.

\section{Method}

\subsection{Sample and Data Collection}

We draw our sample from the financial analysis made easy (FAME) database, which provides information for companies in the UK and Ireland. We applied three criteria in our search strategy: 1) firms should be based in England; 2) the number of employees should not exceed 250; and 3) active firms not in receivership nor dormant. In total, 52,568 firms within the FAME database meet our search criteria. Given the resource constrains to contact firms for data collection, we randomly selected a sampling frame of 5,000 firms from the FAME database. With the samples selected, 1,542 firms provide contact details for their top executives such as business owners, chief executive officers, and managing director. We targeted the top executives of SMEs because they are more likely to have better understanding of firms' strategic orientation and operations (Covin and Wales, 2019). We contacted these firms in May 2015 through an email inviting them to participate in this research but reached only 1,388 firms as some of the addresses were not valid due to some executives having moved to other firms or retired.

We collected 157 online survey responses after three rounds of follow-ups. Due to missing data on focal variables, we dropped 47 cases. Additionally, 22 firms that have less than 10 employees were also removed to ensure the samples used in our study have relative comparable resources and capabilities for EO and ambidexterity (Audia and Greve, 2006; Plambeck, 2012). This leads to a final sample of 88 SMEs used in our study. In particular, the average firm age was 35.5 years. Among the 88 SMEs, 36 of them are small firms with the number of employees ranging from 10 to 50 employees; the remaining 52 cases are medium-sized firms with employee numbers ranging from 51 to 250 employees. The firms come from different industry sectors including 28 firms from manufacturing sector, 37 firms from service sector, and the remaining 23 firms from other sectors. 


\subsection{Measures}

Appendix 1 shows the survey questions used to measure the outcome and causal conditions. All these conditions were measured using five-point Likert scales.

Outcome of interest. Previous research has examined new product performance at different levels: project-level and firm-level. Research that focus on new product performance at the project-level tend to measure the performance of a new product project using item reflecting "time - to - market, technical performance, unit manufacturing cost, and R\&D budget as measured relative to goals" (Tang et al., 2015, p. 413). By contrast, studies that examine new product performance at the firm-level tend to focus on the extent to which the new product development in the firm achieves the targeted objectives on areas such as sales, market share, profitability, and return on investment (Atuahene-Gima and Murray, 2007; Chen et al., 2014). It is well-acknowledged that both EO and ambidexterity are firm-level constructs (Rauch et al., 2009; Simsek, 2009; Wei et al., 2014; Covin and Wales, 2019). To ensure that all focal constructs used in our study are at the same level, we measured new product performance at the firm-level by asking respondents to assess the performance of their new products relative to their objectives on sales, market share, profitability, and return on investment, following Atuahene-Gima and Murray (2007) and Chen et al., (2014).

Causal conditions. Innovativeness, proactiveness, and risk-taking were measured following the nineitem scale widely used in EO research (Covin and Slevin, 1989; Rauch et al., 2009; Covin and Wales, 2012). Exploration and exploitation were measured with four items each adapted from Atuahene-Gima and Murray (2007). Ambidexterity can be operationalised in two distinct ways: combined approach or balanced approach (Junni et al., 2013). The combined approach uses the multiplication or addition of exploration and exploitation to represent the combined ambidexterity. By contrast, the balanced approach uses the subtraction between exploration and exploitation to represent the balanced ambidexterity. Since the EO dimensions are exploratory in nature, we adopted the balanced approach to measure ambidexterity. By ensuring that the exploration measure for ambidexterity is not directly included in our model, this can help to avoid potential overlap between the EO dimensions and 
ambidexterity. Consistent with previous studies (Cao et al., 2009; He and Wong, 2004), we operationalised organisational ambidexterity by using the absolute difference between exploration and exploitation (ranging from 0 to 4). To assist interpretation, we subtract the absolute difference from 5 so that a high value represents high levels of ambidexterity. Market turbulence was measured with a three-item scale adapted from Jaworski and Kohli (1993) to capture the extent of changes in relation to consumer demands.

\subsection{Measure Assessment}

We applied a series of techniques to assess the measures used in the present study. As shown in Appendix 1, all factor loadings were above .40. All Cronbach's alpha and composite reliability were above the recommended value of 0.7 except for market turbulence $(\alpha=0.69)$, which is considered acceptable (Hair et al., 2014). The average variance extracted (AVE) of all constructs were greater than the recommended level of .50 (Bagozzi and Yi, 2012). We removed one item for market turbulence due to cross factor loading in exploratory factor analysis. We estimated a seven-factor measurement model using confirmatory factor analysis (CFA). The results demonstrate an acceptable model fit with confirmatory fit index $(\mathrm{CFI})=.89$, root mean squared error of approximation $(\mathrm{RMSEA})=.072, \chi^{2}$ $($ d.f. $)=302.94(209)$, although the model is significant $(\mathrm{p}<0.01)$. These results demonstrate adequate construct reliability and validity.

\section{Analyses and Results}

\subsection{Data Analysis Method}

Using fsQCA 3.0 software (UC, 2017), we calibrated all variables into fuzzy membership scores ranging from 0 to 1 (Ragin, 2008). A membership score 0 designates "full non-membership", while 1 corresponds to "full membership", and 0.5 represents the "cross-over point". Following prior fsQCA research (Hudson and Kühner, 2013), we set the mean value as the cross-over point, a value with one standard deviation below the mean as full non-membership or fully out, and a value with one standard deviation above the mean as full membership or fully in. Since fsQCA automatically excludes cases 
with a membership score of 0.5 due to maximum ambiguity (Ragin, 2008), we added a 0.001 to cases at the cross-over point to ensure they are not neglected during analysis (Fiss, 2011). Table 1 shows the calibration thresholds and the correlations of the conditions.

Table 1: Calibration thresholds and correlations of the conditions

\begin{tabular}{|c|c|c|c|c|c|c|c|c|}
\hline Conditions & $\begin{array}{l}\text { Fully } \\
\text { out }\end{array}$ & $\begin{array}{l}\text { Cross } \\
\text { over }\end{array}$ & $\begin{array}{l}\text { Fully } \\
\text { in }\end{array}$ & 1 & 2 & 3 & 4 & 5 \\
\hline 1. Innovativeness & 2.55 & 3.40 & 4.25 & & & & & \\
\hline 2. Proactiveness & 2.38 & 3.28 & 4.18 & $.385^{* *}$ & & & & \\
\hline 3. Risk-taking & 1.87 & 2.83 & 3.79 & $.421 * *$ & $.408 * *$ & & & \\
\hline 4. Ambidexterity & 3.23 & 4.02 & 4.81 & .157 & $.329 * *$ & .076 & & \\
\hline 5. Market turbulence & 2.59 & 3.39 & 4.18 & $.335^{* *}$ & .168 & .022 & .065 & \\
\hline 6. New product performance & 2.83 & 3.51 & 4.18 & $.394 * *$ & .110 & $.331 * *$ & -.002 & $.243 *$ \\
\hline
\end{tabular}

Note: correlations are based on the fuzzy membership scores

Based on the fuzzy membership scores, we conducted necessity analysis to assess whether the presence or absence of the individual EO dimensions, ambidexterity, and market turbulence is necessary for the presence or absence of superior new product performance. Results shown in Table 2 suggest that all consistency values were below the threshold of 0.9 (Ragin, 2008; Schneider and Wagemann, 2012). This implies that none of the conditions is a necessary condition for either the presence or the absence of high levels of new product performance.

Table 2: Analysis of necessary conditions for the presence and absence of superior new product performance

\begin{tabular}{|c|c|c|c|c|}
\hline \multirow[t]{2}{*}{ Causal Conditions } & \multicolumn{2}{|c|}{$\begin{array}{c}\text { Presence of superior } \\
\text { new product performance }\end{array}$} & \multicolumn{2}{|c|}{$\begin{array}{c}\text { Absence of superior } \\
\text { new product performance }\end{array}$} \\
\hline & Consistency & Coverage & Consistency & Coverage \\
\hline Innovativeness & 0.70 & 0.71 & 0.47 & 0.44 \\
\hline Innovativeness & 0.45 & 0.48 & 0.69 & 0.68 \\
\hline Proactiveness & 0.69 & 0.70 & 0.51 & 0.49 \\
\hline$\sim$ Proactiveness & 0.50 & 0.52 & 0.69 & 0.67 \\
\hline Risk-taking & 0.61 & 0.62 & 0.56 & 0.52 \\
\hline$\sim$ Risk-taking & 0.53 & 0.56 & 0.59 & 0.58 \\
\hline Ambidexterity & 0.65 & 0.60 & 0.65 & 0.56 \\
\hline$\sim$ Ambidexterity & 0.53 & 0.62 & 0.54 & 0.59 \\
\hline Market turbulence & 0.66 & 0.67 & 0.54 & 0.50 \\
\hline$\sim$ Market turbulence & 0.51 & 0.54 & 0.65 & 0.64 \\
\hline
\end{tabular}

Note: indicates the absence of the causal condition 
We then conducted sufficiency analysis to identify the configurations that are sufficient to produce superior new product performance using a truth table consisting of 32 configurations, calculated as $2^{\mathrm{k}}$, where $\mathrm{k}$ refers to the number of conditions (i.e., 5) used in the present study. We removed configurations that contain no empirical cases. All remaining configurations were coded as 1 (presence of the outcome) or 0 (absence of the outcome) based on the thresholds of above a minimum raw consistency of 0.80 and a proportional reduction in inconsistency consistency of 0.75 (Misangyi and Acharya, 2014; Schneider and Wagemann, 2012). In the final step, the fsQCA use Boolean algebra to derive three solutions: "complex", "parsimonious", and "intermediate" solutions (Ragin, 2008). Consistent with the best practice in fsQCA research (Ragin, 2009; Núñez-Pomar et al., 2016; Pittino et al., 2017), we reported the intermediate solution as it takes into account easy counterfactuals that are in line with theoretical knowledge and prior empirical evidence (Douglas et al., 2020; Fiss, 2011).

\subsection{Configurations for the Presence of Superior New Product Performance}

The left panel of Table 3 presents the configurations (i.e., P1 to P3) of EO dimensions, ambidexterity, and market turbulence that are sufficient for the presence of superior new product performance. The overall solution consistency as well as the consistency for all individual configurations were all above the minimum threshold of 0.75 (Ragin, 2008), indicating the configurations are consistent in explaining the presence of the outcome. The overall solution coverage is 0.28 , demonstrating that a substantial proportion of the outcomes were explained by the configurations.

Configuration P1 suggests the joint presence of innovativeness and proactiveness in combination with absent risk-taking contribute to new product performance within ambidextrous firms, where market turbulence is irrelevant. Configuration P2 implies that combination of innovativeness, proactiveness, and absent risk-taking is sufficient to produce superior new product performance under turbulent market environment, where ambidexterity is irrelevant. Unlike configurations P1 and P2 that entail proactiveness, configuration P3 shows that under turbulent market environment, innovativeness in combination with absent risk-taking can also produce desirable outcome when firms are ambidextrous.

\subsection{Configurations for the Absence of Superior New Product Performance}


As robustness checks, we conducted another set of sufficient analysis to identify the configurations of EO dimensions, ambidexterity, and market turbulence that are sufficient for the absence of superior new product performance. The right panel of Table 3 shows that configurations A1 and A2 are associated with the absence of superior new product performance. Configuration A1 implies that the joint absence of innovativeness and proactiveness hampers new product performance when both ambidexterity and market turbulence are also absent. Configuration A2 shows the joint absence of innovativeness and proactiveness in combination with risk-taking hinders new product performance when market turbulence is absent. All configurations for the absence of the outcome (i.e., A1 \& A2) are distinct from configurations for its presence (i.e., P1 to P3), indicating no contradictory configurations in our study.

Table 3: Analysis of sufficient conditions for the presence and absence of superior new product performance

\begin{tabular}{|c|c|c|c|c|c|}
\hline \multirow[t]{2}{*}{ Causal Conditions } & \multicolumn{3}{|c|}{$\begin{array}{c}\text { Presence of superior } \\
\text { new product performance }\end{array}$} & \multicolumn{2}{|c|}{$\begin{array}{c}\text { Absence of superior } \\
\text { new product performance }\end{array}$} \\
\hline & $\mathrm{P} 1$ & $\mathrm{P} 2$ & P3 & A1 & $\mathrm{A} 2$ \\
\hline Innovativeness & $\bullet$ & $\bullet$ & $\bullet$ & $\circ$ & ○ \\
\hline Proactiveness & $\bullet$ & $\bullet$ & & ○ & o \\
\hline Risk-taking & ○ & ० & $\circ$ & & $\bullet$ \\
\hline Ambidexterity & $\bullet$ & & $\bullet$ & $\circ$ & \\
\hline Market turbulence & & $\bullet$ & $\bullet$ & o & o \\
\hline Consistency & 0.91 & 0.90 & 0.88 & 0.91 & 0.92 \\
\hline Raw coverage & 0.21 & 0.22 & 0.22 & 0.28 & 0.22 \\
\hline Unique coverage & 0.03 & 0.03 & 0.03 & 0.15 & 0.10 \\
\hline Overall solution consistency & 0.89 & & & 0.91 & \\
\hline Overall solution coverage & 0.28 & & & 0.37 & \\
\hline
\end{tabular}

Note: $\bullet(\circ)$ represents the presence (absence) of the causal condition

\section{Discussion and Conclusion}

\subsection{Theoretical contributions}

Since EO is an exploratory orientation that entails uncertain returns, researchers have called for studies to investigate the potential factors that might counterbalance and complement EO to enhance organisational outcomes (Patel et al., 2015; Covin and Wales, 2019) In response to this call, the present 
study integrated the EO literature and organisational learning theory by examining the complementary role of the EO dimensions and ambidexterity in producing superior new product performance. More specifically, we adopted a configurational perspective to examine the configurations of innovativeness, proactiveness, risk-taking and ambidexterity for superior new product performance under different extents of market turbulence. We applied a novel methodological approach in terms of fuzzy set qualitative comparative analysis (fsQCA) to uncover the potential causal complexity among the EO dimensions, ambidexterity, market turbulence, and new product performance (Ragin, 2008; Schneider and Wagemann, 2012).

Building on a configurational perspective, the present study expands the EO literature by showing that the EO dimensions tend to work in combinations rather than in isolation to impact new product performance. Our results demonstrated that all configurations leading to the presence (configurations P1 to P3) as well as the absence (configurations A1 \& A2) of the outcome entail the presence and/or absence of at least two of the EO dimensions, supporting proposition 1a that the individual dimensions alone is not sufficient to produce superior new product performance. Previous research in EO has generated useful insight about how the individual EO dimensions operate independently (Hughes and Morgan, 2007), as well as how they operate in pairs (Lomberg et al., 2016) to impact organisational outcome. We extend this line of research by showing that examining the individual EO dimensions in isolation or in pairs provides only a partial picture about their effects on organisations. Our findings show that we need to examine the EO dimensions holistically as they tend to work together to influence new product performance. For example, configurations P1 and P2 indicate that superior new product performance requires the three dimensions of EO to work together (i.e., joint presence of innovativeness and proactiveness combined with absent risk-taking). Our findings serve to answer recent calls to examine EO from a configurational perspective (Covin and Wales, 2019).

Consistent with proposition $1 \mathrm{~b}$, configurations $\mathrm{P} 1$ and $\mathrm{P} 3$ leading to superior new product performance entail both the EO dimensions and ambidexterity, indicating they complement each other to enhance new product performance. Yet configuration P2 shows that the joint presence of innovativeness and proactiveness in combination with absent risk-taking is sufficient to produce the outcome under 
turbulent market environment, implying ambidexterity is irrelevant. Hence, proposition $1 \mathrm{~b}$ is not fully supported. We speculate that two reasons might explain this finding. First, previous literature suggests that firms operate in dynamic environment can benefit more from EO (Rauch et al., 2009). In line with this view, in a turbulent market environment, firms might gain more benefits from the joint presence of innovativeness and proactiveness and absent risk taking. This might be the reason why the EO dimensions are sufficient to produce superior new product performance without ambidexterity. Second, comparing configurations $\mathrm{P} 2$ and $\mathrm{P} 3$ show that, when other conditions are equal, the benefits from proactiveness might substitute the benefits from ambidexterity. Given the limited research on the complementary roles between the EO dimensions and ambidexterity, further research is still needed to explore how they work together to influence new product performance.

The present study contributes to the EO literature and organisational learning theory by uncovering the complementary role between the EO dimensions and ambidexterity in producing superior new product performance. In line with propositions 2 and 3, configurations P1 and P3 suggest that ambidexterity alone is not sufficient to produce superior new product performance; instead, the presence of superior new product performance requires ambidexterity to be complemented by the EO dimensions. A comparison between configurations $\mathrm{P} 1$ and $\mathrm{P} 3$ also show that the configurations leading to superior new product performance depend on whether market turbulence is present, supporting proposition 4 . While extensive studies suggest EO contributes to firm performance (Rauch et al., 2009; Gupta and Wales, 2017), emerging research has highlighted that the EO dimensions are exploratory in nature that entail uncertain returns (Wiklund and Shepherd, 2011; Patel et al., 2015). This implies that the EO dimensions alone might not be the receipt for long-term success. Our study expands prior works by providing empirical evidence supporting the view of Covin and Wales (2019) that firms are more likely to achieve success (e.g., new product performance) through complementing EO with another factor, in our case ambidexterity. This contribution is important as it shows that in addition to pursue new opportunities through EO, firms also need to cultivate their capability (e.g., ambidexterity) to balance and reconfigure their efforts in exploration and exploitation (O'Reilly and Tushman, 2008; Simsek, 
2009). The reason being that ambidexterity will likely protect firms from over exploration, caused by the EO dimensions, at the expenses of exploitation.

By adopting a configurational perspective using fsQCA (Ragin, 2008; Schneider and Wagemann, 2012), our study also expands research on new product performance in two important ways. Using fsQCA allows us to shed lights on the causal conjunction where the EO dimensions influence new product performance in conjunction with ambidexterity (Schneider and Wagemann, 2012). More specifically, our study uncovers that new product performance is often a function of combinations of the EO dimensions, ambidexterity, and/or market turbulence. As such, to achieve superior new product performance, firms need to align the EO dimensions with the market environment and/or develop the capability to balance exploration and exploitation (Cao et al., 2009; He and Wong, 2004). Additionally, using fsQCA allows us to uncover that firms can achieve superior new product performance through multiple ways (i.e., configurations P1 to P3), indicating causal equifinality (Douglas et al., 2020; Ragin, 2008; Schneider and Wagemann, 2012).

\subsection{Practical implications}

Our findings have important implications for small business owner-mangers on how to leverage the different EO dimensions and ambidexterity for superior new product performance. In particular, firms should manage innovativeness, proactiveness, risk-taking, and ambidexterity holistically by considering their configurations as our findings show that focusing on a causal condition alone is insufficient to produce superior new product performance. For example, our findings show that ambidextrous firms can obtain high levels of new produce performance in two ways. First, ambidextrous firms can benefit from the joint presence of innovativeness and proactiveness in combination with absent risk-taking. Second, they can benefit from the combination of innovativeness with absent risk-taking under a turbulent market environment. These findings show that, to obtain superior new product performance, firms can complement the EO dimensions with ambidexterity; they should also align the combination of EO dimensions and ambidexterity with the market environment in which they operate within. Additionally, for firms operating under a turbulent market environment, they can leverage the joint presence of innovativeness and proactiveness in combination with absent risk- 
taking, where ambidexterity is irrelevant, to obtain superior new product performance. These finding are of particular interest to firms in the UK as well as Ireland, where Brexit is likely to lead to turbulence in the market environment. Firms might benefit from the fact that superior new product performance can be achieved in various ways that do not always require firms to take high risks. Instead firms should focus on how they can best complement their existing innovation strategy to achieve ambidexterity. While Brexit might provide new opportunities, there is a danger for firms to over explore at the expense of exploitation. As such we encourage small business owner-managers to develop their capability to balance and reconfigure exploration and exploitation efforts.

\subsection{Limitations and future research}

While our study offers important contributions to extant literature, it is important to consider its limitations that provides opportunities for future research. One limitation concerns the size and heterogeneity of the sample used in our study limiting the generalisability from our findings. While we limited our sample to SMEs with 10 to 250 employees, small firms might differ from medium-sized firms on their resources and capabilities. Hence, further research might need to look at a larger sample of firms with similar size to rule out potential effects caused by differences in resources and capabilities.

Likewise, the industry sector in which firms operate within might have an impact on EO and new product development. Firms from different industry sectors tend to experience different product life cycles, as well as different levels of competition and uncertainty in the market environment (Wang et al., 2015; Wu, 2012; Bierly and Daly, 2007). This implies that they are likely to differ in their needs to engage in entrepreneurial activities (e.g., the EO dimensions) to renew themselves (Lumpkin and Dess, 1996). Indeed, some researcher have found that service and manufacturing firms tend to differ in their levels of EO (Rigtering et al., 2014). Furthermore, the competition and uncertainty in the market environment might impact the outcome of new product development (Tsai and Huang, 2008). As such, future research efforts could devise sector-specific studies to better gauge how configurations of the EO dimensions and ambidexterity work together to influence new product performance. We used subjective measures for new product performance following prior research (Akgün et al., 2006; Atuahene-Gima 
and Murray, 2007). Future research efforts could employ financial performance data to verify whether the configurations identified in the present study hold with objective performance outcomes.

\subsection{Conclusion}

To conclude, the present study contributes to the literature of EO and organisational learning theory by uncovering that superior new product performance is a function of the EO dimensions in combination with ambidexterity and/or market turbulence. It also reveals the complementary role of the EO dimensions and ambidexterity in shaping new product performance. We hope the present study will inspire additional research to adopt a configurational perspective to explore other factors that might complement the EO dimensions to enhance organisational outcomes. 


\section{References:}

Akgün, A.E., Lynn, G.S. and Byrne, J.C. (2006), "Antecedents and consequences of unlearning in new product development teams", Journal of Product Innovation Management, Vol. 23 No. 1, pp. 73-88.

Alvarez, S.A. (2007), "Entrepreneurial rents and the theory of the firm", Journal of Business Venturing, Vol. 22 No. 3, pp. 427-442.

Andersén, J. (2010), “A critical examination of the EO-performance relationship", International Journal of Entrepreneurial Behavior \& Research, Vol. 16 No. 4, pp. 309-328.

Anderson, B.S., Kreiser, P.M., Kuratko, D.F., Hornsby, J.S. and Eshima, Y. (2015), "Reconceptualizing entrepreneurial orientation", Strategic Management Journal, Vol. 36 No. 10, pp. 1579-1596.

Andriopoulos, C. and Lewis, M.W. (2009), "Exploitation-exploration tensions and organizational ambidexterity: Managing paradoxes of innovation", Organization Science, Vol. 20 No. 4, pp. 696-717.

Atuahene-Gima, K. and Murray, J.Y. (2007), "Exploratory and exploitative learning in new product development: A social capital perspective on new technology ventures in China", Journal of International Marketing, Vol. 15 No. 2, pp. 1-29.

Audia, P.G. and Greve, H.R. (2006), "Less likely to fail: Low performance, firm size, and factory expansion in the shipbuilding industry", Management Science, Vol. 52 No. 1, pp. 83-94.

Bagozzi, R.P. and Yi, Y. (2012), "Specification, evaluation, and interpretation of structural equation models", Journal of the Academy of Marketing Science, Vol. 40 No. 1, pp. 8-34.

Baum, J.A.C., Li, S.X. and Usher, J.M. (2000), "Making the next move: How experiential and vicarious learning shape the locations of chains' acquisitions", Administrative Science Quarterly, Vol. 45 No. 4, pp. 766-801.

Bierly, P.E. and Daly, P.S. (2007), "Alternative knowledge strategies, competitive environment, and organizational performance in small manufacturing firms", Entrepreneurship Theory and Practice, Vol. 31 No. 4, pp. 493-516.

Buganza, T., Dell'Era, C. and Verganti, R. (2009), "Exploring the relationships between product development and environmental turbulence: The case of Mobile TLC Services", Journal of Product Innovation Management, Vol. 26 No. 3, pp. 308-321.

Cao, Q., Gedajlovic, E. and Zhang, H. (2009), "Unpacking organizational ambidexterity: Dimensions, contingencies, and synergistic effects", Organization Science, Vol. 20 No. 4, pp. 781-796.

Chen, Y., Tang, G., Jin, J., Xie, Q. and Li, J. (2014), “CEOs' transformational leadership and product innovation performance: The roles of corporate entrepreneurship and technology orientation", Journal of Product Innovation Management, Vol. 31, pp. 2-17.

Covin, J.G. and Slevin, D.P. (1989), "Strategic management of small firms in hostile and benign environments", Strategic Management Journal, Vol. 10 No. 1, pp. 75-87.

Covin, J.G. and Wales, W.J. (2012), "The measurement of entrepreneurial orientation", Entrepreneurship: Theory \& Practice, Vol. 36 No. 4, pp. 677-702.

Covin, J.G. and Wales, W.J. (2019), "Crafting high-impact entrepreneurial orientation research: Some suggested guidelines", Entrepreneurship Theory and Practice, Vol. 43 No. 1, pp. 3-18.

Dimov, D. (2017), "Towards a qualitative understanding of human capital in entrepreneurship research", International Journal of Entrepreneurial Behavior \& Research, Vol. 23 No. 2, pp. 210-227.

Douglas, E.J., Shepherd, D.A. and Prentice, C. (2020), "Using fuzzy-set qualitative comparative analysis for a finer-grained understanding of entrepreneurship", Journal of Business Venturing, Vol. 35 No. 1, p. 105970.

European Commission. (2015), "User guide to the SME definition", Luxembourg: Publications Office of the European Union.

Faruk Şahin, Hande Karadağ and Büşra Tuncer. (2019), "Big five personality traits, entrepreneurial self-efficacy and entrepreneurial intention : A configurational approach", International Journal of Entrepreneurial Behavior \& Research, Vol. 25 No. 6, pp. 1188-1211. 
Ferreira, J., Coelho, A. and Moutinho, L. (2018), "Dynamic capabilities, creativity and innovation capability and their impact on competitive advantage and firm performance: The moderating role of entrepreneurial orientation", Technovation, available at:https://doi.org/10.1016/j.technovation.2018.11.004.

Fiss, P.C. (2011), "Building better causal theories: A fuzzy set approach to typologies in organization research", Academy of Management Journal, Vol. 54 No. 2, pp. 393-420.

George, B.A. (2011), "A theoretical and empirical examination of the consequences of differing construct representations", Journal of Management Studies, Vol. 48 No. 6, pp. 1291-1313.

Gibson, C.B. and Birkinshaw, J. (2004), "The antecedents, consequences, and mediating role of organizational ambidexterity", Academy of Management Journal, Vol. 47 No. 2, pp. 209-226.

Golder, P.N. and Tellis, G.J. (1993), "Pioneer advantage: Marketing logic or marketing legend?", Journal of Marketing Research (JMR), Vol. 30 No. 2, pp. 158-170.

Gupta, A.K., Smith, K.G. and Shalley, C.E. (2006), "The interplay between exploration and exploitation", Academy of Management Journal, Vol. 49 No. 4, pp. 693-706.

Gupta, V.K. and Wales, W.J. (2017), "Assessing organisational performance within entrepreneurial orientation research: Where have we been and where can we go from here?", The Journal of Entrepreneurship, Vol. 26 No. 1, pp. 51-76.

Hair, J.F., Black, W.C., Babin, B.J. and Anderson, R.E. (2014), Multivariate data analysis, 7th ed., Pearson, Harlow.

He, Z.-L. and Wong, P.-K. (2004), "Exploration vs. exploitation: An empirical test of the ambidexterity hypothesis", Organization Science, Vol. 15 No. 4, pp. 481-494.

Hudson, J. and Kühner, S. (2013), "Beyond indices: The potential of fuzzy set ideal type analysis for cross-national analysis of policy outcomes", Policy and Society, Vol. 32 No. 4, pp. 303-317.

Hughes, M. and Morgan, R.E. (2007), "Deconstructing the relationship between entrepreneurial orientation and business performance at the embryonic stage of firm growth", Industrial Marketing Management, Vol. 36 No. 5, pp. 651-661.

Hultink, E.J., Griffin, A., Hart, S. and Robben, H.S. (1997), "Industrial new product launch strategies and product development performance", Journal of Product Innovation Management, Vol. 14 No. 4, pp. 243-257.

Jaworski, B.J. and Kohli, A.K. (1993), "Market orientation: antecedents and consequences", Journal of Marketing, Vol. 57 No. 3, pp. 53-70.

Junni, P., Sarala, R.M., Taras, V. and Tarba, S.Y. (2013), “Organizational ambidexterity and performance: A meta-analysis", Academy of Management Perspectives, Vol. 27 No. 4, pp. 299-312.

Katila, R. and Ahuja, G. (2002), "Something old, something new: A longitudinal study of search behavior and new product introduction", Academy of Management Journal, Vol. 45 No. 6, pp. $1183-1194$.

Keh, H.T., Nguyen, T.T.M. and Ng, H.P. (2007), "The effects of entrepreneurial orientation and marketing information on the performance of SMEs", Journal of Business Venturing, Vol. 22 No. 4, pp. 592-611.

Kleinschmidt, E.J. and Cooper, R.G. (1991), "The impact of product innovativeness on performance", Journal of Product Innovation Management, Vol. 8 No. 4, pp. 240-251.

Kreiser, P.M., Marino, L.D., Kuratko, D.F. and Weaver, K.M. (2013), "Disaggregating entrepreneurial orientation: the non-linear impact of innovativeness, proactiveness and risktaking on SME performance", Small Business Economics, Vol. 40 No. 2, pp. 273-291.

Lavie, D., Stettner, U. and Tushman, M.L. (2010), "Exploration and exploitation within and across organizations", The Academy of Management Annals, Vol. 4 No. 1, pp. 109-155.

Li, Y.-H. and Huang, J.-W. (2012), “Ambidexterity's mediating impact on product development proficiency and new product performance", Industrial Marketing Management, Vol. 41 No. 7, pp. $1125-1132$.

Linton, G. and Kask, J. (2017), "Configurations of entrepreneurial orientation and competitive strategy for high performance", Journal of Business Research, Vol. 70, pp. 168-176.

Lomberg, C., Urbig, D., Stöckmann, C., Marino, L.D. and Dickson, P.H. (2016), "Entrepreneurial orientation: The dimensions' shared effects in explaining firm performance", Entrepreneurship Theory and Practice, Vol. 41 No. 6, pp. 973-998. 
Lumpkin, G.T. and Dess, G.G. (1996), "Clarifying the entrepreneurial orientation construct and linking it to performance", Academy of Management Review, Vol. 21 No. 1, pp. 135-172.

March, J.G. (1991), "Exploration and exploitation in organizational learning", Organization Science, Vol. 2 No. 1, pp. 71-87.

Miller, D. (2011), "Miller (1983) Revisited: A reflection on EO research and some suggestions for the future", Entrepreneurship Theory and Practice, Vol. 35 No. 5, pp. 873-894.

Miller, D. and Friesen, P.H. (1983), "Strategy-making and environment: The third link", Strategic Management Journal, Vol. 4 No. 3, pp. 221-235.

Misangyi, V.F. and Acharya, A.G. (2014), "Substitutes or complements? A configurational examination of corporate governance mechanisms", Academy of Management Journal, Vol. 57 No. 6, pp. 1681-1705.

Morgan, R.E. and Strong, C.A. (2003), "Business performance and dimensions of strategic orientation", Journal of Business Research, Vol. 56 No. 3, pp. 163-176.

Núñez-Pomar, J., Prado-Gascó, V., Añó Sanz, V., Crespo Hervás, J. and Calabuig Moreno, F. (2016), "Does size matter? Entrepreneurial orientation and performance in Spanish sports firms", Journal of Business Research, Vol. 69 No. 11, pp. 5336-5341.

O'Reilly, C.A. and Tushman, M.L. (2008), “Ambidexterity as a dynamic capability: Resolving the innovator's dilemma”, Research in Organizational Behavior, Vol. 28, pp. 185-206.

Patel, P.C., Kohtamäki, M., Parida, V. and Wincent, J. (2015), "Entrepreneurial orientation-asexperimentation and firm performance: The enabling role of absorptive capacity", Strategic Management Journal, Vol. 36 No. 11, pp. 1739-1749.

Pérez-Luño, A., Wiklund, J. and Cabrera, R.V. (2011), "The dual nature of innovative activity: How entrepreneurial orientation influences innovation generation and adoption", Journal of Business Venturing, Vol. 26 No. 5, pp. 555-571.

Pittino, D., Visintin, F. and Lauto, G. (2017), "A configurational analysis of the antecedents of entrepreneurial orientation”, European Management Journal, Vol. 35 No. 2, pp. 224-237.

Plambeck, N. (2012), "The development of new products: The role of firm context and managerial cognition", Journal of Business Venturing, Vol. 27 No. 6, pp. 607-621.

Polites, G.L., Roberts, N. and Thatcher, J. (2012), "Conceptualizing models using multidimensional constructs: a review and guidelines for their use", European Journal of Information Systems, Vol. 21 No. 1, pp. 22-48.

Porter, M.E. (1980), Competitive Strategy: Techniques for Analyzing Industries and Competitors, Free Press, New York.

Ragin, C. (2009), "Qualitative comparative analysis using fuzzy sets (fsQCA)", in Rihoux, B. and Ragin, C. (Eds.), Configurational Comparative Methods: Qualitative Comparative Analysis (QCA) and Related Techniques, Sage, Thousand Oaks, CA, pp. 87-121.

Ragin, C.C. (2008), Redesigning Social Inquiry: Fuzzy Sets and Beyond, University of Chicago Press.

Raisch, S. and Birkinshaw, J. (2008), "Organizational ambidexterity: Antecedents, outcomes, and moderators", Journal of Management, Vol. 34 No. 3, pp. 375-409.

Rauch, A., Wiklund, J., Lumpkin, G.T. and Frese, M. (2009), "Entrepreneurial orientation and business performance: An assessment of past research and suggestions for the future", Entrepreneurship Theory and Practice, Vol. 33 No. 3, pp. 761-787.

Rigtering, J.P.C., Kraus, S., Eggers, F. and Jensen, S.H. (2014), "A comparative analysis of the entrepreneurial orientation/growth relationship in service firms and manufacturing firms", The Service Industries Journal, Vol. 34 No. 4, pp. 275-294.

Rosenbusch, N., Brinckmann, J. and Bausch, A. (2011), "Is innovation always beneficial? A metaanalysis of the relationship between innovation and performance in SMEs", Journal of Business Venturing, Vol. 26 No. 4, pp. 441-457.

Rosenbusch, N., Rauch, A. and Bausch, A. (2013), "The mediating role of entrepreneurial orientation in the task environment-performance relationship: A meta-analysis", Journal of Management, Vol. 39 No. 3, pp. 633-659.

Schnaars, S.P. (2002), Managing Imitation Strategies, Simon and Schuster.

Schneider, C.Q. and Wagemann, C. (2012), Set-Theoretic Methods for the Social Sciences: A Guide to Qualitative Comparative Analysis, Cambridge University Press. 
Simsek, Z. (2009), “Organizational ambidexterity: Towards a multilevel understanding", Journal of Management Studies, Vol. 46 No. 4, pp. 597-624.

Smith, K.G. and Cao, Q. (2007), "An entrepreneurial perspective on the firm-environment relationship", Strategic Entrepreneurship Journal, Vol. 1 No. 3-4, pp. 329-344.

Srinivasan, R., Haunschild, P. and Grewal, R. (2007), "Vicarious learning in new product introductions in the early years of a converging market", Management Science, Vol. 53 No. 1, pp. 16-28.

Tang, F., Mu, J. and Thomas, E. (2015), "Who knows what in NPD teams: Communication context, mode, and task contingencies", Journal of Product Innovation Management, Vol. 32 No. 3, pp. 404-423.

Teece, D.J. (2007), "Explicating dynamic capabilities: The nature and microfoundations of (sustainable) enterprise performance", Strategic Management Journal, Vol. 28 No. 13, pp. 1319-1350.

Tsai, M.-T. and Huang, Y.-C. (2008), "Exploratory learning and new product performance: The moderating role of cognitive skills and environmental uncertainty", The Journal of High Technology Management Research, Vol. 19 No. 2, pp. 83-93.

Tushman, M.L. and O'Reilly, C.A. (1996), “Ambidextrous organizations: Managing evolutionary and revolutionary change", California Management Review, Vol. 38 No. 4, pp. 8-30.

UC, I. (2017), “University of California, Irvine.2017. fsQCA.”, available at: http:// www.socsci.uci.edu/ cragin/fsQCA/software.shtml.

Uotila, J., Maula, M., Keil, T. and Zahra, S.A. (2009), "Exploration, exploitation, and financial performance: analysis of S\&P 500 corporations", Strategic Management Journal, Vol. 30 No. 2, pp. 221-231.

Wang, C.L., Senaratne, C. and Rafiq, M. (2015), "Success traps, dynamic capabilities and firm performance", British Journal of Management, Vol. 26 No. 1, pp. 26-44.

Wei, Z., Yi, Y. and Guo, H. (2014), "Organizational learning ambidexterity, strategic flexibility, and new product development", Journal of Product Innovation Management, Vol. 31 No. 4, pp. 832-847.

Wiklund, J. and Shepherd, D. (2003), "Knowledge-based resources, entrepreneurial orientation, and the performance of small and medium-sized businesses", Strategic Management Journal, Vol. 24 No. 13, pp. 1307-1314.

Wiklund, J. and Shepherd, D.A. (2011), "Where to from here? EO-as-experimentation, failure, and distribution of outcomes", Entrepreneurship: Theory \& Practice, Vol. 35 No. 5, pp. 925-946.

Wu, J. (2012), "Technological collaboration in product innovation: The role of market competition and sectoral technological intensity", Research Policy, Vol. 41 No. 2, pp. 489-496.

Zahra, S.A. and George, G. (2002), "Absorptive capacity: A review, reconceptualization, and extension”, Academy of Management Review, Vol. 27 No. 2, pp. 185-203. 


\begin{tabular}{|c|c|}
\hline Scales & $\begin{array}{l}\text { Factor } \\
\text { Loading }\end{array}$ \\
\hline \multicolumn{2}{|l|}{ Innovativeness $(\alpha=.82 ; \mathrm{CR}=.78 ; \mathrm{AVE}=.54)$} \\
\hline We favour a strong emphasis on R\&D, technological leadership, and innovations & .74 \\
\hline My firm has many new lines of products marketed in the past 3 years & .77 \\
\hline Changes in our product lines have usually been quite dramatic & .69 \\
\hline \multicolumn{2}{|l|}{ Proactiveness $(\alpha=.79 ; \mathrm{CR}=.80 ; \mathrm{AVE}=.54)$} \\
\hline We initiate actions to which competitors then respond & .71 \\
\hline $\begin{array}{l}\text { We are very often the first business to introduce new products, administrative } \\
\text { techniques, operating technologies, etc. }\end{array}$ & .77 \\
\hline We typically adopt a very competitive, "undo-the-competitors" posture & .73 \\
\hline \multicolumn{2}{|l|}{ Risk-taking $(\alpha=.89 ; \mathrm{CR}=.86 ; \mathrm{AVE}=.68)$} \\
\hline We have a strong propensity for high-risk projects (with chances of very high returns) & .86 \\
\hline $\begin{array}{l}\text { We believe, owing to the nature of the environment, that bold, wide-ranging acts are } \\
\text { necessary to achieve the firm's objectives }\end{array}$ & .82 \\
\hline $\begin{array}{l}\text { When there is uncertainty, we typically adopt a bold, aggressive posture in order to } \\
\text { maximise the probability of exploiting potential opportunities }\end{array}$ & .80 \\
\hline \multicolumn{2}{|l|}{ Exploration $(\alpha=.78 ; \mathrm{CR}=.81 ; \mathrm{AVE}=.52)$} \\
\hline $\begin{array}{l}\text { We preferred to collect information with no identifiable market needs to ensure } \\
\text { experimentation }\end{array}$ & .49 \\
\hline $\begin{array}{l}\text { We collected novel information and ideas that went beyond our current market and } \\
\text { technological experiences }\end{array}$ & .80 \\
\hline $\begin{array}{l}\text { In information search, we focused on acquiring information and ideas involving } \\
\text { experimentation and high market risks }\end{array}$ & .72 \\
\hline $\begin{array}{l}\text { Our aim was to acquire knowledge to develop products that involves learning new } \\
\text { areas such as markets and technologies }\end{array}$ & .83 \\
\hline \multicolumn{2}{|l|}{ Exploitation $(\alpha=.78 ; \mathrm{CR}=.86 ; \mathrm{AVE}=.60)$} \\
\hline $\begin{array}{l}\text { Our aim was to search for information to refine common methods and ideas in solving } \\
\text { problems }\end{array}$ & .69 \\
\hline $\begin{array}{l}\text { Our aim was to search for ideas and information that we can implement well to ensure } \\
\text { predictable outcome }\end{array}$ & .79 \\
\hline We searched for proven ideas and solutions to product development problems & .79 \\
\hline $\begin{array}{l}\text { We emphasised the use of knowledge related to our existing product and market } \\
\text { experiences }\end{array}$ & .81 \\
\hline \multicolumn{2}{|l|}{ Market turbulence $(\alpha=.69 ; \mathrm{CR}=.81 ; \mathrm{AVE}=.68)$} \\
\hline Customers' product preferences change quite a bit over time & .86 \\
\hline Our customers tend to look for new products all the time & .79 \\
\hline $\begin{array}{l}\text { We are witnessing demand for our products from customers who never bought them } \\
\text { before * }\end{array}$ & - \\
\hline \multicolumn{2}{|l|}{ New product performance $(\alpha=.86 ; \mathrm{CR}=.89 ; \mathrm{AVE}=.66)$} \\
\hline Sales objectives & .77 \\
\hline Profit objectives & .85 \\
\hline Market share objectives & .82 \\
\hline Return on investment objectives & .82 \\
\hline
\end{tabular}

*Item removed due to cross loading

$\alpha=$ Cronbach's alpha; $\mathrm{CR}=$ composite reliability; $\mathrm{AVE}=$ average variance extracted. 